\title{
Successful management of rectovaginal fistula treated by endorectal advancement flap: report of two cases and literature review
}

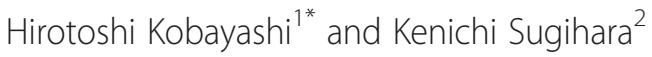

\begin{abstract}
Introduction: Rectovaginal fistula (RVF) sometimes has a difficulty in treatment. This report describes two patients who suffered from RVF.

Case descriptions: One patient was a 76-year-old woman who had a RVF over 30 years after the 3rd childbirth. She underwent endorectal advancement flap (ERAF). She had a nighttime soiling after ERAF once a month, which disappeared one year after surgery. Second patient was a 23-year-old woman who had a RVF one month after the first childbirth. She underwent ERAF, and did not have any complications.

Discussion and evaluation: Both patients did not develop recurrence for four years. Quality of life after ERAF was satisfactory in both patients. ERAF is a safe procedure in terms of both short and long outcomes. We also present a review of the literature concerning ERAF for RVF.
\end{abstract}

Conclusions: ERAF can be a potential option as a treatment for RVF.

Keywords: Rectovaginal fistula; Endorectal advancement flap

\section{Background}

There is a low incidence of rectovaginal fistula (RVF) in developed countries. RVF sometimes occur after childbirth (Lowry et al. 1988; Rothenberger et al. 1982; Wise et al. 1991) and is sometimes difficult for cure. Endorectal advancement flap (ERAF) is one of options as a treatment for RVF in the world. We herein describe two patients with RVF who were successfully treated by ERAF. To our knowledge, this is the first reported cases of RVF treated by ERAF in Japan. In addition, we report a review of the literature concerning ERAF for RVF.

\section{Case presentation}

\section{Patient 1}

A 76-year-old woman with RVF was referred to our hospital. She suffered from RVF over 30 years after the third childbirth. A fistula was found at the level of dentate line by the anoscope examination. Similarly, colonoscopy

\footnotetext{
* Correspondence: h-kobayashi.srg2@tmd.ac.jp

${ }^{1}$ Center for Minimally Invasive Surgery, Tokyo Medical and Dental University,

1-5-45 Yushima, Bunkyo-ku, Tokyo 113-8519, Japan

Full list of author information is available at the end of the article
}

also showed a fistula at the same level (Figure 1). She underwent ERAF under the diagnosis of RVF (Figure 2a). She was placed at the jack-knife position. The procedure of ERAF was same as previously mentioned (Rothenberger et al. 1982). In short, a four-centimeter-long flap which consisted of mucosa, submucosa, and circular muscle was outlined around the fistula (Figure $2 \mathrm{~b}$ ). The base was two times as wide as the apex of the flap for adequate blood supply. After the resection of the fistula, circular muscle was sutured by horizontal mattress manner (Figure 2c). The flap was advanced over the repaired area (Figure 2d). She had a good postoperative course and was discharged from hospital on the 7th postoperative day. She had a nighttime soiling once a month, but it disappeared one year after surgery.

\section{Patient 2}

A 23-year-old woman with RVF was referred to our department during the second pregnancy. She suffered from RVF after the first childbirth. After the second childbirth via Caesarean section, contrast radiography showed the discharge from anal canal to vagina (Figure 3). 


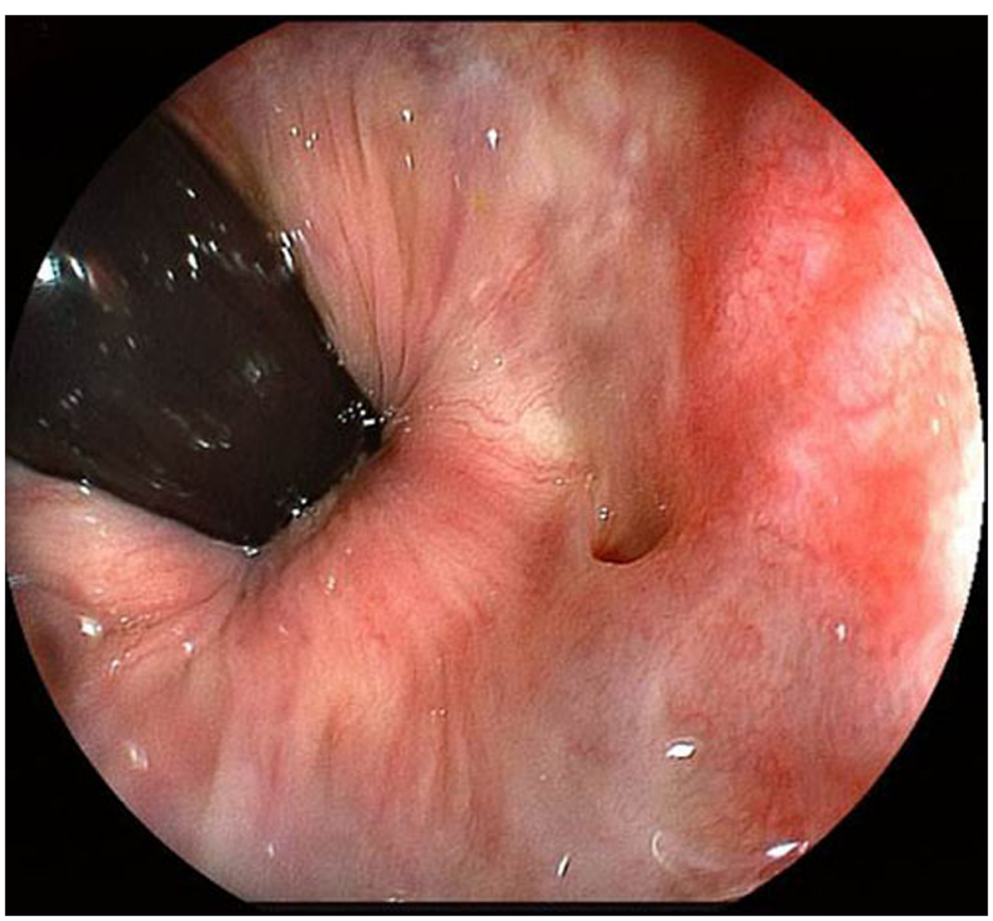

Figure 1 Rectovaginal fistula seen in the colonoscopy.
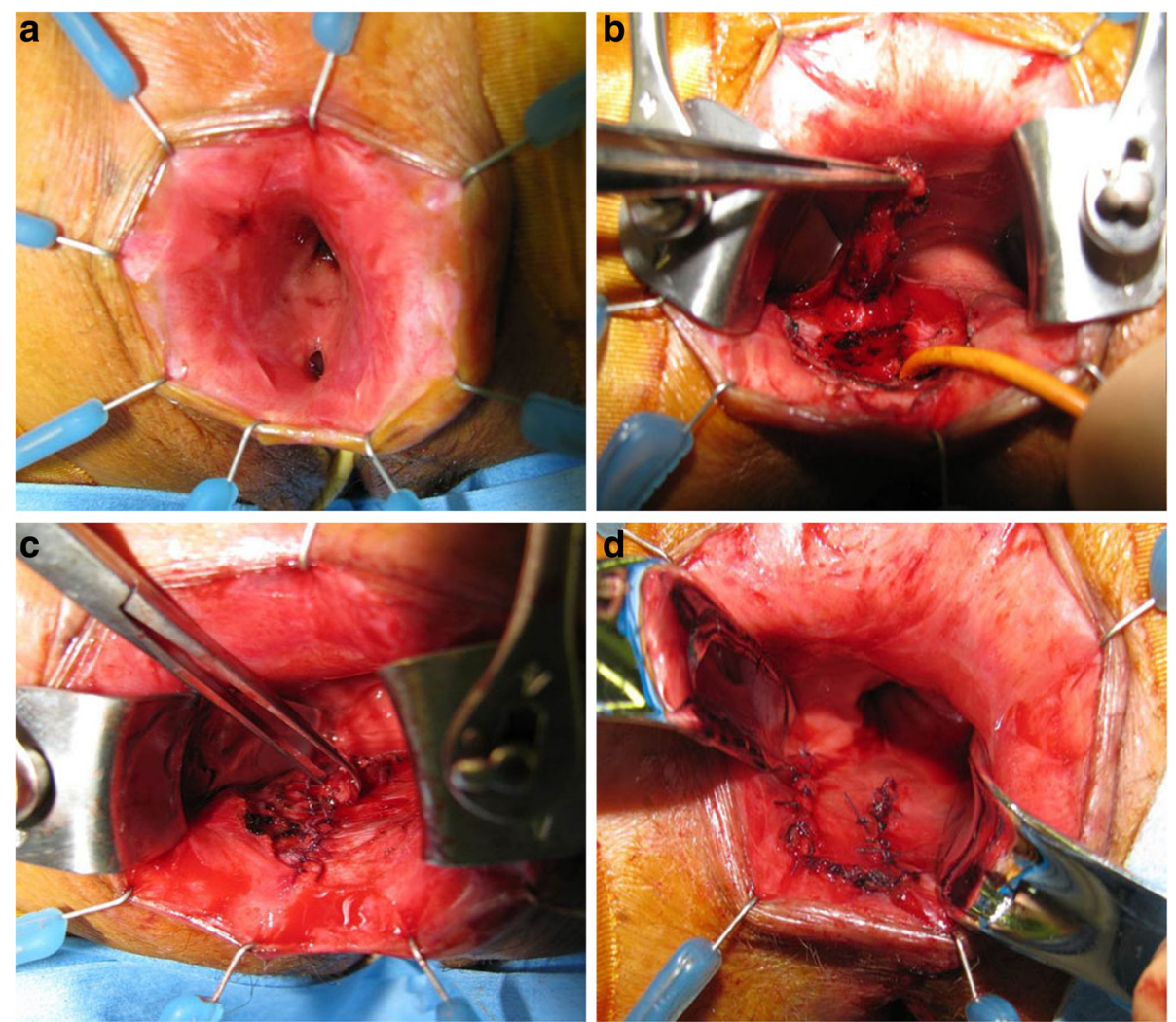

Figure 2 Endorectal advancement flap for rectovaginal fistula. Rectovaginal fistula is seen from the anus (a). The flap of mucosa, submucosa, and circular muscle is raised (b). Circular muscle is sutured by horizontal mattress manner (c). The flap is advanced over the repaired area (d). The flap is sutured in place at its apex and along its sides. 


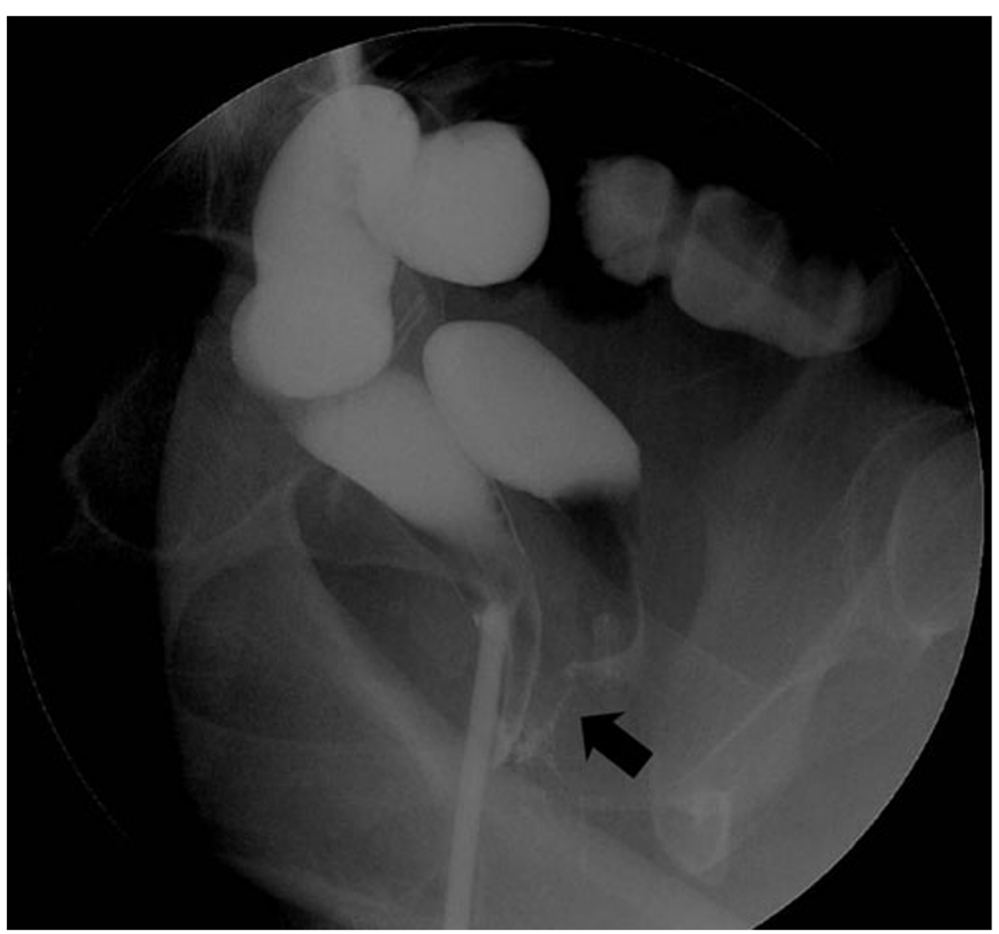

Figure 3 Contrast radiography. Black arrow shows rectovaginal fistula.

She underwent ERAF and had a good postoperative course. She was discharged from hospital on the 7th postoperative day. She did not have any complications.

\section{Discussion}

The incidence of RVF in developed counties is low, but RVF is sometimes refractory.

The incidence of RVF after vaginal delivery is $0.1 \%$ to 0.5\% (Goldaber et al. 1993; Venkatesh et al. 1989). RVF at the lower level is usually caused by obstetric events. RVF at the higher level is caused by radiotherapy or rectal surgery in many cases.

Since ERAF for RVF was firstly reported in 1982 (Rothenberger et al. 1982), it has been one of the standard treatments for RVF. This procedure is a modification of mucosal flap reported by Laird (Laird 1948). Complete excision of the fistula tract is important. A flap consists of mucosa, submucosa, and circular muscle in this technique. After excision of the fistula tract, internal sphincter muscle is mobilized. Then, internal sphincter muscle is approximated in the midline without tension. In Japan, there has been no article regarding ERAF for RVF. To the best of our knowledge, this is the first report concerning ERAF for RVF in Japan. We searched the associated articles through Medline using the key words of 'rectovaginal fistula' and 'endorectal advancement flap'. Thirteen English papers were matched (Table 1) (de Parades et al. 2011; Devesa et al. 2007; Joo et al. 1998; Kodner et al. 1993;
Loffler et al. 2009; Lowry et al. 1988; Ozuner et al. 1996; Pinto et al. 2010; Rothenberger et al. 1982; Sonoda et al. 2002; Stern et al. 1988; Tsang et al. 1998; Wise et al. 1991). Among these, six papers included the cases of fistul-inano (Joo et al. 1998; Kodner et al. 1993; Loffler et al. 2009; Ozuner et al. 1996; Pinto et al. 2010; Sonoda et al. 2002).

The most frequent cause of RVF was an obstetric event (Kodner et al. 1993; Lowry et al. 1988; Rothenberger et al. 1982; Wise et al. 1991). Recently, RVF associated with Crohn's disease has been increasing (de Parades et al. 2011; Joo et al. 1998; Kodner et al. 1993; Loffler et al. 2009; Ozuner et al. 1996; Pinto et al. 2010; Sonoda et al. 2002). The median age of RVF varied from 30.5 to 45.5 years old. Duration of disease was 12 months to 31.2 months. The average number of procedure was 1.47 (Pinto et al. 2010). Therefore, the recurrence after the treatment for RVF is problematic. The cure rate of RVF was $41 \%$ to $91 \%$ (de Parades et al. 2011; Devesa et al. 2007; Joo et al. 1998; Kodner et al. 1993; Loffler et al. 2009; Lowry et al. 1988; Ozuner et al. 1996; Pinto et al. 2010; Rothenberger et al. 1982; Sonoda et al. 2002; Stern et al. 1988; Tsang et al. 1998; Wise et al. 1991). Devesa et al. reported that the success rate of ERAF for simple rectovaginal fistula was $100 \%$ (Devesa et al. 2007). In the present study, both patients had simple RVF and succeeded in the treatment. Lowry et al. reported that the cure rates in the first, the second, and the third procedures were $88 \%, 85 \%$, and 55\%, respectively (Lowry et al. 1988). Another paper 
Table 1 Literature review of endorectal advancement flap for rectovaginal fistula

\begin{tabular}{|c|c|c|c|c|c|c|c|c|c|c|}
\hline Author & Year & No. of Pts & Age & Cause & Size & Location & $\begin{array}{l}\text { Median } \\
\text { duration } \\
\text { of fistula }\end{array}$ & $\begin{array}{l}\text { Period of } \\
\text { follow-up }\end{array}$ & $\begin{array}{l}\text { Rate of } \\
\text { cure }\end{array}$ & Complication \\
\hline Rothebnerger et al. & 1982 & 35 & $35(18-77)$ & $\begin{array}{l}\text { Obstetric operative injury in } \\
4 \text { Infection in } 1\end{array}$ & $\begin{array}{l}\text { Average } 1 \mathrm{~cm} \\
\text { most were less } \\
\text { than } 2.5 \mathrm{~cm}\end{array}$ & NA & NA & 2 years & $91 \%$ & NA \\
\hline Lowry et al. & 1988 & 81 & $34(18-76)$ & $\begin{array}{l}\text { An unknown cause in } 6 \text { Obstetrical } \\
\text { injury in } 74 \% \text { Perineal infection in } \\
10 \% \text { Operative Trauma in7\% } \\
\text { Unknown in } 8 \%\end{array}$ & Less than $2.5 \mathrm{~cm}$ & NA & NA & NA & $83 \%$ & NA \\
\hline Stern et al. & 1988 & 10 & $28-74$ & Mainly trauma & NA & NA & NA & NA & $70 \%$ & NA \\
\hline Wise et al. & 1991 & 40 & $32.5(20-51)$ & $\begin{array}{l}\text { Obstetric in } 25 \text { Infectious in } 8 \\
\text { Posttoperative in } 2 \text { Unknown in } 5\end{array}$ & NA & $\begin{array}{l}\text { With in } \\
1 \mathrm{~cm} \text { of the } \\
\text { dentate line }\end{array}$ & NA & NA & $82.5 \%$ & $\begin{array}{l}\text { Early Recurrence } \\
2 \text { Urinary tract infection } \\
1 \text { Urinary retention } \\
1 \text { Wound complication } \\
3 \text { Late Incontinence } \\
\text { Gas/Liquid } 5 \text { Solid } 2\end{array}$ \\
\hline Kodner et al. & 1993 & 71 & $38(20-71)$ & $\begin{array}{l}\text { Obstetric injury, } 48 \text { Cryptoglandular } \\
\text { abscess-fistula,31 Cronhn's disease, } \\
24 \text { Trauma or after operation } 4\end{array}$ & NA & NA & NA & NA & $84 \%$ & NA \\
\hline Ozuner et al. & 1996 & 52 & $38(17-67)$ & $\begin{array}{l}\text { Obstetric injury } 13 \text { Cryptoglandular } \\
\text { abscess-fistula, } 19 \text { Crohn's disease, } \\
47 \text { Trauma or after operation, } \\
15 \text { Mucosalulcerative colitis, } 7\end{array}$ & Less than $3 \mathrm{~cm}$ & NA & 12 moths & 31 months & $71 \%$ & NA \\
\hline Joo et al. & 1998 & 20 & $40.2(16-70)$ & Crohn's disease & NA & NA & NA & 17.3 months & $75 \%$ & $\begin{array}{l}\text { Flap retraction in } \\
1 \text { patient }\end{array}$ \\
\hline Tsang et al. & 1998 & $\begin{array}{l}52 \\
\text { (62 procedures) }\end{array}$ & $30.5(18-70)$ & $\begin{array}{l}\text { Obstetrical Obstetric injury } \\
\text { in } 5 \text { Cryptoglandular } \\
\text { abscess-fistula in } 48\end{array}$ & NA & NA & $\mathrm{Na}$ & NA & 41 & $\begin{array}{l}\text { Bleeding in } \\
1 \text { patient } 23 \%\end{array}$ \\
\hline Sonoda et al. & 2002 & 37 & $42(16-78)$ & $\begin{array}{l}\text { Crohn's disease in } 44 \text { Trauma or } \\
\text { after operation in } 1 \text { Other in } 1\end{array}$ & NA & NA & NA & 17.1 mothd & $63.6 \%$ & NA \\
\hline Devesa et al. & 2007 & 46 & 41 & NA & NA & NA & NA & NA & $\begin{array}{l}100 \% \text { simple } \\
\text { fistula }\end{array}$ & NA \\
\hline Loffler et al. & 2009 & 45 & NA & Cronhn's disease Obstetric injury in 5 & NA & NA & NA & 48 moths & $53 \%$ & NA \\
\hline de Parades et al. & 2011 & 23 & 45.5 & $\begin{array}{l}\text { Cryptoglandular disease in } 11 \\
\text { Crohn's disease in } 7 \text { Obstetric } \\
\text { in } 18 \text { Crohn's in } 38\end{array}$ & NA & NA & NA & 14 months & $65 \%$ & NA \\
\hline Pinto et al. & 2010 & 75 procedure & 41.8 & $\begin{array}{l}\text { Traumatic in } 7 \text { Muscosalulcerative } \\
\text { colitis in } 3 \text { Others in } 9\end{array}$ & $\begin{array}{l}<0.5 \mathrm{~cm} 47.8 \% \\
0.5-1.0 \mathrm{~cm} 35.9 \% \\
>1.0 \mathrm{~cm} 16.3 \%\end{array}$ & $\begin{array}{l}\text { Low } 78.6 \% \\
\text { Middle } 15.7 \% \\
\text { High } 5.7 \%\end{array}$ & 31.2 months & 20.1 months & $56.3 \%$ & NA \\
\hline
\end{tabular}


demonstrated that the most important factor associated with cure in patients with RVF was form: whether it was simple or complex (Devesa et al. 2007). Ozuner et al. disclosed that Crohn's disease was associated with the highest recurrence rate among the various causes of RVF (Ozuner et al. 1996). Especially, the success rate was lower in patients with Crohn's disease accompanying small intestinal lesion (Joo et al. 1998). Therefore, ERAF is considered useful in patients with simple RVF after obstetric event.

Accurate diagnosis is mandatory before surgery. However, contrast radiography for rectovaginal fistula is sometimes difficult, because contrast radiography can only detect high rectovaginal fistulae unless the applicator does not extend the level of the internal anal opening.

There are some limitations in this study. There are a variety of treatments for rectovaginal fistula. Transverse transperineal approach as well as transabdominal approach exists. In some cases, Martius flap can be another option for RVF (Elkins et al. 1990). However, we could not compare these techniques in this study, because of lack of RVF cases.

\section{Conclusions}

We experienced two patients with RVF who were treated by ERAF successfully. Simple RVF after obstetric event is considered good indication for ERAF. ERAF can be a potential option for RVF in Japan.

\section{Consent}

Written informed consent was obtained from the patient for the publication of this report and any accompanying images.

\section{Competing interests}

The authors declare that they have no competing interests.

\section{Authors' contributions}

HK designed this study and collected the data. HK and KS wrote the manuscript. Both authors read and approved the final manuscript.

\footnotetext{
Author details

${ }^{1}$ Center for Minimally Invasive Surgery, Tokyo Medical and Dental University, 1-5-45 Yushima, Bunkyo-ku, Tokyo 113-8519, Japan. ${ }^{2}$ Department of Surgical Oncology, Graduate School, Tokyo Medical and Dental University, Tokyo, Japan.
}

Received: 10 December 2014 Accepted: 6 January 2015

Published online: 15 January 2015

\section{References}

de Parades V, Dahmani Z, Blanchard P, Zeitoun JD, Sultan S, Atienza P (2011) Endorectal advancement flap with muscular plication: a modified technique for rectovaginal fistula repair. Colorectal Dis 13:921-925

Devesa JM, Devesa M, Velasco GR, Vicente R, Garcia-Moreno F, Rey A, LopezHervas P, Die J, Molina JM (2007) Benign rectovaginal fistulas: management and results of a personal series. Tech Coloproctol 11:128-134

Elkins TE, DeLancey JO, McGuire EJ (1990) The use of modified Martius graft as an adjunctive technique in vesicovaginal and rectovaginal fistula repair. Obstet Gynecol 75:727-733
Goldaber KG, Wendel PJ, McIntire DD, Wendel GD, Jr (1993) Postpartum perineal morbidity after fourth-degree perineal repair. Am J Obstet Gynecol 168:489-493

Joo JS, Weiss EG, Nogueras JJ, Wexner SD (1998) Endorectal advancement flap in perianal Crohn's disease. Am Surg 64:147-150

Kodner IJ, Mazor A, Shemesh El, Fry RD, Fleshman JW, Birnbaum EH (1993) Endorectal advancement flap repair of rectovaginal and other complicated anorectal fistulas. Surgery 114:682-689. discussion 689-690

Laird DR (1948) Procedures used in treatment of complicated fistulas. Am J Surg 76:701-708

Loffler T, Welsch T, Muhl S, Hinz U, Schmidt J, Kienle P (2009) Long-term success rate after surgical treatment of anorectal and rectovaginal fistulas in Crohn's disease. Int J Colorectal Dis 24:521-526

Lowry AC, Thorson AG, Rothenberger DA, Goldberg SM (1988) Repair of simple rectovaginal fistulas. Influence of previous repairs. Dis Colon Rectum 31:676-678

Ozuner G, Hull TL, Cartmill J, Fazio WW (1996) Long-term analysis of the use of transanal rectal advancement flaps for complicated anorectal/vaginal fistulas. Dis Colon Rectum 39:10-14

Pinto RA, Peterson TV, Shawki S, Davila GW, Wexner SD (2010) Are there predictors of outcome following rectovaginal fistula repair? Dis Colon Rectum 53:1240-1247

Rothenberger DA, Christenson CE, Balcos EG, Schottler JL, Nemer FD, Nivatvongs S, Goldberg SM (1982) Endorectal advancement flap for treatment of simple rectovaginal fistula. Dis Colon Rectum 25:297-300

Sonoda T, Hull T, Piedmonte MR, Fazio WW (2002) Outcomes of primary repair of anorectal and rectovaginal fistulas using the endorectal advancement flap. Dis Colon Rectum 45:1622-1628

Stern H, Gamliel Z, Ross T, Dreznik Z (1988) Rectovaginal fistula: initial experience. Can J Surg 31:359-362

Tsang CB, Madoff RD, Wong WD, Rothenberger DA, Finne CO, Singer D, Lowry AC (1998) Anal sphincter integrity and function influences outcome in rectovaginal fistula repair. Dis Colon Rectum 41:1141-1146

Venkatesh KS, Ramanujam PS, Larson DM, Haywood MA (1989) Anorectal complications of vaginal delivery. Dis Colon Rectum 32:1039-1041

Wise WE, Jr, Aguilar PS, Padmanabhan A, Meesig DM, Arnold MW, Stewart WR (1991) Surgical treatment of low rectovaginal fistulas. Dis Colon Rectum 34:271-274

\section{Submit your manuscript to a SpringerOpen ${ }^{\circ}$ journal and benefit from:}

- Convenient online submission

Rigorous peer review

- Immediate publication on acceptance

- Open access: articles freely available online

- High visibility within the field

- Retaining the copyright to your article

Submit your next manuscript at $\gg$ springeropen.com 